\title{
地 域経済と基地
}

\author{
仲宗 根一勇* \\ は じ め に
}

戦後沖繩社会に加わった大きなインパクトとしては，引揚者による人口急增などがあるが， 何よりも大きかったのは米軍による軍事基地の建設であったことは明かである。基地の建設 は，沖繩の自然条件を变光，社会的経済的諸条件にも大きな変化をもたらした。地形その他の 自然的条件の変化は, 特定物としての土地の位置境界を不明確なるのとしてしまって現在に至 るまで問題を残している。るた基地の建設は，農地の接収を通じて人々を農業から離脱させ， 集落を排除してその再編を余儀なくさせた。農業からの離脱, 基地建設への就業と, 米軍及び 集った人及を対象としたサービス業, 商業等の成立と定着を通じて, 戦前に見られなかった新 しい産業構造の基礎ができ上った（第 1 表，第 2 表参照)。

集落の排除と再編は，人口の新しい場所へのはりつきと集積をもたらして現在の都市構造の 原型をつくりあげた。

また本土との分離，米国による統治，自治の制限を通じて，米軍が「地域を構成する主体の 一員」として加わり，政策主体としての役割をも担って登場した。

このような各面における変化は，沖繩の社会および人々の生活様式，意識構造等にも大きな 影響を及ぼした。基地建設のインパクトは，「沖繩の中に基地があるのでなく，基地の中に沖 繩がある」と言わせるに充分な程大きかったし，経済については「基地経済」と表現されるに

第 1 表 地区別提供施設面積

(昭和 51 年 12 月末現在)

\begin{tabular}{|c|c|c|c|c|c|c|c|c|c|}
\hline & & & \multirow{2}{*}{$\begin{array}{c}\text { 陸地面 積 } \\
\text { (A) }\end{array}$} & \multirow{2}{*}{$\frac{\text { 軍 }}{\text { 計 }(B)}$} & \multirow{2}{*}{$\begin{array}{l}\text { 用 } \\
\text { 米 軍 }\end{array}$} & \multirow{2}{*}{$\begin{array}{r}\text { 面 } \\
\text { 自衛隊 }\end{array}$} & \multirow{2}{*}{$\frac{\text { 積 }}{\text { VOA }}$} & \multirow{2}{*}{$\begin{array}{l}\text { 軍用地 } \\
\text { 点拠率 } \\
(\mathrm{B}) /(\mathrm{A})\end{array}$} & \multirow{2}{*}{$\begin{array}{l}\text { 軍 用 地 } \\
\text { 構成割合 }\end{array}$} \\
\hline & & & & & & & & & \\
\hline 全 & & 県 & $\begin{array}{r}\mathrm{km}^{2} \\
2,245.87\end{array}$ & $\begin{array}{r}\mathrm{km}^{2} \\
269.27\end{array}$ & $\begin{array}{r}\mathrm{km}^{2} \\
264.87\end{array}$ & $\begin{array}{l}\mathrm{km}^{2} \\
3.30\end{array}$ & $\begin{array}{l}\mathrm{km}^{2} \\
1.10\end{array}$ & $12.0^{\%}$ & $\begin{array}{r}\% \\
(100.0)\end{array}$ \\
\hline \multirow[t]{4}{*}{ 沖 } & 繩 本 & 島 & $1,434.49$ & 268.25 & 263.96 & 3. 19 & 1.10 & 18.7 & 99.6 \\
\hline & 北 & 部 & 784.04 & 177.14 & 175.80 & 0.30 & 1.04 & 22.6 & 66.0 \\
\hline & 中 & 部 & 268.75 & 79.72 & 79.22 & 0.44 & 0.06 & 29.6 & 29.7 \\
\hline & 南 & 部 & 381.70 & 11.39 & 8.94 & 2.45 & - & 3.0 & 4.2 \\
\hline 宮 & & 古 & 226.96 & 0.11 & - & 0.11 & - & 0.0 & 0.0 \\
\hline 八 & 重 & 山 & 584.42 & 0.92 & 0.92 & - & - & 0.2 & 0,3 \\
\hline
\end{tabular}

* 琉球大学 
第 2 表 地目 別 利 用 現 況

\begin{tabular}{|c|c|c|c|c|c|c|c|}
\hline \multirow[b]{2}{*}{ 農 } & \multirow[b]{2}{*}{ 用 } & \multirow[b]{2}{*}{ 地 } & \multirow{2}{*}{$\begin{array}{c}\text { 面 } \begin{array}{r}\text { 積 } \\
\text { (昭和50年) }\end{array} \\
\mathrm{km}^{2} \\
454\end{array}$} & \multirow{2}{*}{$\frac{\text { 構 成 比 }}{20.2^{\%}}$} & \multirow{2}{*}{$\begin{array}{c}\begin{array}{c}\text { 軍用 地面 積 } \\
\text { (昭和51年 } 3 \text { 月赑) }\end{array} \\
\mathrm{km}^{2} \\
54\end{array}$} & \multirow{2}{*}{$\begin{array}{c}\text { 構 成 比 } \\
19.8\end{array}$} & \multirow{2}{*}{$\begin{array}{c}\text { 軍用地の占 } \\
\text { る割合 } \\
\% \\
11.9\end{array}$} \\
\hline & & & & & & & \\
\hline 森 & & 林 & 1,051 & 46.8 & \multirow{2}{*}{198} & \multirow{2}{*}{72.5} & \multirow{2}{*}{14.0} \\
\hline 原 & & 野 & 365 & 16.4 & & & \\
\hline 道 & & 路 & 70 & 3.1 & - & - & - \\
\hline & 河 & k路 & 21 & 0.9 & - & - & - \\
\hline 宅 & & 地 & 62 & 2.8 & 6 & 2.2 & 9.7 \\
\hline \multirow[t]{2}{*}{ そ } & の & 他 & 223 & 9.9 & 15 & 5.5 & 6.7 \\
\hline & 計 & & 2,246 & $(100.0)$ & 273 & $(100.0)$ & 12.2 \\
\hline
\end{tabular}

資料： 沖繩県」沖繩振興開発計画の後期における課題と施策」(䓩) 昭和 52 年 9 月 ふさわしいものであった。

本報告に执いては，沖繩の地域社会の現在の構造を規定したこの基地インパクトの波及を， 主ととして経済的側面について概観し，今後の地域開発に関して問題提起を試みる。

\section{1. 経 済成長 と基地}

沖繩経済と基地との関わりは，米軍余剩物資の供給を受けそれを消費するといらことから始 められた。その後ガリオア等による消費物資の援助の形でこのような関わりがかなりの期間続 いた。中共の成立，朝鮮動乱を契機として恒久基地保有の基本方針が決定され，基地建設が始 められると，沖繩がいわゆる基地需要に対して供給する側に立つ関係が生ずる。

基地需要は, 基地建設の過程にあっては, 建設需要が中心であった。この建設需要は, 沖繩 の建設業の育成発展の端緒となった。基地建設が一段落した段階においては, 軍人軍属および その家族による個人消費需要が多くなり, これがサービス業, 商業を中心として第三次産業を 発展させる契機となった。

いわゆる基地需要とよばれるものの中にはその他に生産用役に対する需要がある。すなわち 労働および土地に対する需要であって, それぞれに対して軍雇用者賃金, 軍用地代という要素 費用の支払がなされている。この要素への需要＝要素費用支払の増大は結局住民所得の増大で あってこれが沖繩経済の成長動因の一つであった。

ただこ〉で留意しておかねばならないのはこれらの生産要素の活用が, 産業としての生産活 動ではないといらことである。軍雇用については，いわば「出稼ぎ」と同じであり，軍用地に 関しても単に軍用地代といら所得の稼得機会を持つといらに過ぎないのである。基地が雇用の 場となり，あるいは土地といら生産要素を需要したといってもそれは産業としての働きをもつ ものではなかった。軍事基地を産業として位置づけるのは虚像を見ることになる。

ところで経済成長への貢献は, 建設需要, 個人消費需要あるいは労働, 土地等生産要素への 
需要を介してばかりではなかった。基地は, 沖繩においては, 社会的間接資本の働きをもって 沖繩の経済成長に寄与してきた。

基地といらのは, 狭義に解釈すれば，囲い込まれた軍用地の中だけを指す。したがってそれ は，いわば沖繩という地域社会以外の地域として囲い込まれているのであって，その中にある 各種施設の働きは, 生産資本としても社会資本としても沖繩経済に何らの働きをもつものとは いえない。

しかしながら基地を围い込みの中だけに限定して把握することは，きわめて一面的のそしり を免れない。何故なら基地は，沖繩内において，相互に結合され統合されており，困い込みの 中だけで完結しているのではないからである。

「沖繩の中に基地があるのではなく，基地の中に沖繩がある」といらのは，沖繩の特性をよ く表現しているが，これは基地が囲い込みの中丈で完結せず，道路網によって連結され，電 力, 上下水道等の供給処理施設のネットワークも統合されているといら事実に立脚したもので ある。これらの連結, 統合されている諸施設は, また軍事目的のために割当てられた米軍の予 算によって建設されたものであり，その意味でも軍用地といら囲い込みの単位で基地を理解し てはならない。この外部の連結, 統合の諸施設も基地の一部として建設されたものであり, そ のよらに理解すべきである。要するに軍事機能を果すためには，囲い込みの外にある施設も必 要不可欠のものであったし現在もそうである。したがって沖繩の基地の働きを，軍事的な意味 にしろあるいは経済的な意味にしろ, 囲い込みの中の施設についてのみ評価するのは, 妥当で はない。

以上のように基地を理解すると，基地はある種の社会資本の働きをしたと評価することがで きよう。とくに，旧 1 号線（現国道 58 号線）をはじめとする主要軍用道路が，沖繩の産業基 盤の役割を担い, 都市形成の軸となり，生活各面に与えた影響は計り知れないものがある。電 力にしろ水道にしろ, 基地への供給が同時に沖繩に対する供給であってそれらの基本施設が社 会資本の役割の一部を担い産業基盤，生活基盤として利用されたのである。

以上のような基地需要その他の働きの他に基地は, 沖繩の財政を介して経済規模の拡大に寄 与してきた。ガリオアに始まる援助は, 緊急時の救済のためのものであったが, 基地保有の方 針が定まるに及んで基地保持のための援助に变化した。

米国援助は, 沖繩の財政において大きな比重を占め, 道路, 港湾, 学校, 医療施設その他の 社会的間接資本の形成を可能ならしめ産業基盤, 生活基盤の形成を通じて経済成長に貢献した。 援助の基本的動機は, 基地の維持であったであろらから, 援助水準は十分ではなく援助対象も 制約されたものではあったが，沖繩の経済発展にとってそれなりに必要な財政需要をみたすと いら重要な働きをもったといえよう。 


\section{2. 経 済構 造 と基 地}

基地需要を目途とした産業の成立は建設業においてはじまった。基地建設が一段落して基地 の維持の段階に入ると, サービス業, 商業を中心とした第三次産業が成立発展した。米国軍人 軍属, その家族等の個人消費需要はホテル, 飲食店, バー・キャバレー等の隆盛をもたらした。 それは，二部の製造業たとえばベット，椅子等の家具製造業の成立へと波及したがきわめて微 々たるものだったといえよう。サービス産業への傾斜については，沖繩の産業が安易についた といら厳しい評価もあり得るが，反面そこに需要があったために経済活動としては至極当然だ といら見方も成り立つであろう。たぶ第一次産業や第二次産業とくに工業の成立発展にとって はそれがマイナス要因となり現在の産業構造をつくりあげたといえる。サービス業，商業等の 成立発展は, 米軍の大きな需要が所在したことと同時に, 主な生産要素が人間労働であり少額 資本で対応できたこと, また組織, 技術の面でもとれ程高度のものを要求されなかったこと等 が支えとなった。工業等は, 需要があってもとの企業化に当っては, 組織, 技術, 資本労働等 何れに打いても一段と厳しい努力を必要としたことから著しく立ち遅れたものとなった。基地 の維持運営に直接的必要をもたなかったことが，政策の支持展開を積極化し得なかったことも 一つの大きな理由と考えられる。また必要物資の供給は, 米国および日本本土の既成の産業に 依存する方が安定的で安価であった事も見逃してはならない。

\section{3. 都市の構造と基地}

沖繩の地域構造にみられる特性の一つほ, 都市が沖繩本島中南部にかたよっていることであ る。このような構造の起因は何かというとすでにくりか述べたように「基地」であった。

農業が生活の基盤であった戦前は，農地との結びつきで集落形成がみられたが，今や基地と の結びつきで市街地が形成された。基地建設は, 土地利用に拈いては, 軍用地の拡大としてあ らわれたが, それは集落の移転, 再配置でもあった。その後基地依存産業の成立発展は, 基地 周辺市街地の発展となり, 都市的土地利用の萠芽となっている。都市化の進展は, 人口, 産業 の集積であったと同時に農業的土地利用の駆逐でもあった。

軍用地に怙ける集落の排除一移転一再編一都市形成のプロセスには幾つかの類型がみられ る。

その一つは, 嘉手納一北谷村にみられるように, 基地と基地の狭間に, 新集落が押し込めら れたタイプである。

第二のタイプは宜野湾市に典型的にみられるが, 基地から排除された集落が, 基地の周辺を とりかこむ形となった所である。いわば縁辺分散型と呼んでよいであろら。

さらに第三のタイプは, 旧コザ市にみられるように, 同一方向に排除され, 集約化のプロセ 
スをたどった場合である。いわば集中型と呼び得る。第一のタイプも集中型の一つであろう が, 発展の余地といら点で問題のあらわれ方が異なる。第一のタイプの場合, 基地の狭間にあ って面積が狭いために集積密度が過度であり, 過密化していると同時に発展拡大に限界がみら れる。とくに自然条件が他との連結を妨げていること，および行政単位として独立しているこ となどの条件が重なっている。つまり地形等自然的条件による阻害があると同時に合併による 解決可能性子残されているといってよい。

第二のタイプは, 基地を囲繞して市街地が形成されているため, いわば緣辺線上の集積のみ が可能であり, 都市の集約化, 都市機能の集積, 円滑な運営を阻害するものとなっている。宜 野湾市の普天間空港の所在がこのタイプであり, 基地は市街地分断の役割を果している。まと まりを欠く市街地は, 学校その他の公共施設の配置に際して問題であり都市の機能を著しく阻 害する。また異質の機能の混在が, 地域の調和を破壊し, 騷音が居住の快適性を損い, 事故の 発生可能性が安全性を損っている。この周辺が住居地域であり, また沖繩国際大学があり, 琉 球大学の新キャンパスが近接している事にも留意しておく必要がある。排出集落は線上にはり ついたが，その後外側へ向って分散的に発展せざるを得ない状態となっている。

第三のタイプは, 基地からの排除が, 部分的なものにとぶまり, 一方的に集約されたタイプ である。一方向への集約であったために市街地集積の効率が高くかなりスピードアップして発 展拡大した。しかしその集積要因が基地依存のものであったことからその後も引続いて依存的 性格を強めてきた。沖繩市がその典型である。沖繩市においては, 主要集落への沖繩人収容所 の配置, 嘉手納空港第 2 ゲートの位置, 施設建設の規模が大きく雇用量の多い基地機能である こと, 米軍軍人軍属の居住, 往来の多かったこと等から都市の発展が加速された。

\section{4. 政 策主 体 と基 地}

基地経済の政策主体は外国である米国であった。しかし国民への配慮と，外国人である統治 住民への配虑は，同質にみえても全く異質のものである。心情的表現をかりるならば「血のつ ながり」があるかないかのちがいといってもよい。それは根本的動機において異なるものであ る。

米国，米軍の基本動機は，基地の維持であり，米国の国防政策のごく小さな一端を荷らもの として対沖繩政策があったといえよう。それは, 経済政策と呼ぶにふさわしいものではなかっ た。交通政策も道路行政も基地間を結ぶことが第一義であった。そのため幹線道路は軍管理で あり, 歩道を欠いた構造であった。PLO, 電力, 水の供給管理も同様であって, 基地維持のし くみの中できわめて重要な役割をになった。米軍への供給と抱き合わせの民間への供給は, 民 政府一般資金と呼ばれる会計の中で管理され，油脂類の供給価格におけるマージンや料金収入 
が，電力，水等の供給施設建設に使用され，一部は弁務官資金として市町村へ配分された。ま た一部は道路建設に向けられたこともあったが，しかしこれも基幹軍用道路である旧 1 号線の バイパス建設で，あくまで軍道の効率的機能維持を基本動機としたものといえよう。先述した ように, サービス業に対する政策的配慮も，基地の維持運営に必要とされる点から行われたと 考えられ，たとえば A サイン店（米軍の軍人軍属およびその家族の利用が，公衆衛生その他 の基準で合格である店）の認可等も主眼は同じである。

この政策主体が，復帰によって「日本政府および県」に变化した。しかし血のつながりを欠 いたものから血のつながりのあるものへと变化したにもかっわらず何かそこにはもら少し立ち 入って分析しないと解明できないものがあると思われる。復帰運動が，血の濃さから生まれた ものとしても，戦時中血のつながりを信じていたのが，日本軍によってららぎられ，その後， 分離統治を肯定是認することによって母国からつき離されてきたことが何か沖繩の人々の意識 に，経済に関してさえも異質の判断基準をもちこんでいることがよく指摘されるからである。

\section{5. 基地と開発の諸問題}

以上の経過を踏んで現在の沖繩の地域構造ができ上ったのであるが，基地は現在いろいろな 変化を生じている。その基地の変化とともに，地域の開発にもさまざまな問題が生じているし また今後生み出されると思われる。

問題の一つは，今まで成長要因であったところの「基地」が，成長要因たり得なくなってい ることから生ずる（第 3 表参照)。基地需要が 経済成長の一翼を担ってきたことは前述したと おりであるが，これの低迷は，同時に経済全体の低迷でもある。そこに出てくる要請は，基地 需要に代る需要の創出でありこの代替需要を何に求めるのかは大きな課題である。生産要素に 対する需要減退に対しても同様である。軍基地からの解雇排出労働力をどこで雇用するのか, 開放された軍用地を何に利用して，現在までの地代所得の稼得機会を確保したらい〉のかなど である。先述したように軍雇用とか軍用地の問題は，「産業」に和ける雇用とか土地利用では ないが，そうである丈にこれの解雇とか開放は，まさに産業の問題としてとりあげられねばな らないのである。つまり雇用機会の創出と, 新しい土地利用が, 労働, 土地, 資本といら生産 要素の結合の問題としてとりあげられねばならない。

一部には，財政に期待する声も大きい。また観光需要への対応を説く人もいる。さらに工業 化の推進を唱える人もいる。

財政と 観光の双方が 期待されたのが海洋博であった。財政需要, 観光需要の抱き合せ需要 は, それなりに効果は大きかった。しかし需要は, 一過性であるならば, その低迷がその後の 経済不振に直結する。 
第 3 表 軍関係受取と地域経済

（単位：〈億円）

\begin{tabular}{|c|c|c|c|c|c|c|}
\hline 年 & 45 & 46 & 47 & 48 & 49 & 50 \\
\hline 県民総 生 産 & 3,159 & 3,692 & 5,123 & 7,349 & 8,911 & 10,389 \\
\hline 対前年増加率 （\%) & $(14.4)$ & (16.9) & $(38$ & $(43.5)$ & $(21.3)$ & (16.6) \\
\hline 県民 所 得 （分配） & 2,781 & $\varepsilon, 266$ & 4,377 & 6,297 & 7,655 & 9,009 \\
\hline うち雇用者所得 & 1,395 & 1,696 & 2,191 & 3,263 & 4,296 & 5,158 \\
\hline 得ち個人貨貸料所 & 270 & 294 & 484 & 607 & 735 & 834 \\
\hline 外受取 総 額 & 1, $928(100.0)$ & $2,505(100.0)$ & $3,772(100.0)$ & $5,430(100.0)$ & $6,658(100.0)$ & $8,009(100.0)$ \\
\hline 軍 関 係 受 取 & $714(37.0)$ & $727(29.0)$ & $658(17.4)$ & $707(13.0)$ & $858(12.9)$ & $899(11.2)$ \\
\hline 軍雇用者関係 & $239(12.4)$ & $248(9.9)$ & $186(4.9)$ & $262(4.8)$ & $297(4.5)$ & $317(4.0)$ \\
\hline 軍 用 地 料 & $34(1.7)$ & $31(1.2)$ & $126(3.3)$ & $182(3.4)$ & $264(4.0)$ & $269(3.4)$ \\
\hline 軍人·軍属の消 & $441(22.9)$ & $448(17.9)$ & $345(9.1)$ & $263(4.8)$ & $296(4.4)$ & $314(3.9)$ \\
\hline 観 光 収 入 & $200(10.4)$ & $259(10.3)$ & $409(10.8)$ & $476(8.8)$ & $575(8.6)$ & $1,277(15.9)$ \\
\hline 移（輸）出 & $517(26.8)$ & $652(26.0)$ & $972(25.8)$ & $1,258(23.2)$ & $2,073(31.1)$ & $2,353(29.4)$ \\
\hline $\begin{array}{l}\text { うち砂糖・パイ } \\
\text { シ罐詰 }\end{array}$ & 202 & $152(6.1)$ & $178(4.7)$ & $205(3.8)$ & $215(3.2)$ & $307(3.8)$ \\
\hline うち石油製品 & $0(\quad 0.0)$ & $2(0.1)$ & $473(12.5)$ & $713(13.1)$ & $1,379(20.7)$ & $1,646(20.6)$ \\
\hline $\begin{array}{l}\text { 買外加ら財政への } \\
\text { 移転 }\end{array}$ & $248(12.9)$ & $379(15.1)$ & $1,673(44.4)$ & $2,297(42.3)$ & $3,390(50.9)$ & $3,728(46.5)$ \\
\hline その他 & $128(6.6)$ & $126(5.0)$ & $29(\quad 0.8)$ & $35(0.6)$ & $21(\quad 0.3)$ & $40(0.5)$ \\
\hline $\begin{array}{l}\text { 県外に対する債務 } \\
\text { 純増 }\end{array}$ & $120(6.2)$ & $361(14.4)$ & $32(\quad 0.8)$ & $657(12.1)$ & $\triangle 259(\triangle 3.9)$ & $\triangle 287(\triangle 3.6)$ \\
\hline $\begin{array}{l}\text { 開係受取/県民総生産(\%) } \\
\text { 貨金十軍地料)/悬民所 }\end{array}$ & 22.6 & 19. & 12. & 9. & 9.6 & 8.7 \\
\hline (\%) & 9. & 8. & 7. & 7.0 & 7.3 & 6.5 \\
\hline 雇貨金/ & 17 & 1 & 8. & 8.0 & 6.9 & 6.1 \\
\hline 軍用地代/個人賃貸料（\%) & 12.6 & 10.5 & 26.0 & 30.0 & 35.9 & 32.3 \\
\hline
\end{tabular}

凟料： 沖繩県企画調整部 昭和 50 年度県民所得統計

また経済構造とくに産業構造が，持続的需要への適応を欠くならば同様に根本解決は不可能 である。基地需要へ対応してきた産業構造を，新しい需要へ適合した産業構造に改めることが もら一つの課題であろら。

囲い込まれた基地自体の変化, および基地をとりまく地域社会の変化に由来する問題も重要 である。その中でとくに大事なのは都市の構造および機能とその変化の基地との関わり合いで ある。

囲い込まれた基地の機能, 位置, 広がりと前述した生産物市場, 生産要素市場における需要 を介して, また社会資本としての機能をもつ基地は, 企業の設備投資の種類, 大きさおよび立 地を決定し，またそれらが複合的に働いて，個人住宅建設の位置と大きさを決め現在の都市を 形成してきた。基地は, 産業の育成, 人口集積の原動力となり, 現在の都市構造をつくりあげ たといえる。

このことは基地が総体として，人口，産業，を吸引する働きをもったことを意味する。そし てその働きは，一方に拈いて都市化の進展として，他方において過眯化の進化としてあらわれ 
たといってよい。現在沖繩のかっえている都市問題, 離島問題は, 直接的にしろ, 間接的にし ろ基地との関わりをもつものといらことができる。

都市化の進展は, 学校, 道路その他社会資本の必要したがって財政需要を増大させ, 地価の 高騰等が財政負担増加の誘因となって社会資本形成の困難を生ぜしめている。

また集中のエネルギーは，地域に許容能力のない場合は，人口，産業のスプロールとなって あらわれるが，基地の位置と大きさによって，一方で抑止的に，他方で助長的に㗢くことによ ってスプロールの方向が決定され，市街地の分断，变形を生ぜしめている。

また，基地機能は，多かれ少なかれ地域社会との摩擦は避けられず，騒音その他の公害発生 といらマイナスの働きをもっている。すなわち地域の生活環境を悪化させ，これが地域の財政 負担を増大させ，北部の森林等における訓練，演習が自然を破壊し，その結果土砂流亡等によ る災害を発生させ，資源の有効利用の妨げとなっている点等見逃してはならない。

都市の構造において開発に際して問題を投げかけているのは，とくに基地から排出されて環 状にはりついて形成された第二のタイプの都市であろら。宜野港市はその典型であって，転用 を図るべき基地に順位を付すとすれば普天間基地が第 1 ではなかららか。この基地は，中南部 都市圈の中心部に位置し，面積が 広大であり，市街地を分断している。この分断によって行 政, 教育, 経済, 文化等各面において都市機能を低くしている。またその機能が飛行場である ことは, 周辺機能と共存し調和を図ることを困難としており, この所在が地域の安全性, 快適 性の確保を不可能としている。このような事態に対して抜本的対策を講ずることが必要であ る。

復帰前そして現在に至るすで「基地」は古くて新しい問題であるが，基地に対する人々の態 度には，ある種の变化がみられる。たとえば革新市町村といわれるところでも，反戦反基地の 政策と, 基地をもつ自治体の「財政欠損のカバーや基地存在に伴ら迷惑料的な助成を国が行ら のは当然で何ら矛盾しない」との考方方が支配的となりつ〉あり，基地交付金調整交付金を拒 否してきた自治体がむしろ積極的に整備対策を要請しつつあるといわれる。

また返還が進むにつれて基地との利害が直接的であった人々はそれへの対応を迫られている。 地主は軍用地代所得の確保, 自らの欲する土地利用, 財産所有権の確保等から, ミクロ的に個 別利害にからまる問題としてらけとめそれぞれに対策を講じつ〉ある。

市町村が財政上の理由で問題をとらえるのも止むを得ない点もあるらが，地域におけける政策 主体であるならば，個別の動機にとらわれず全体的立場に立って基地問題に対処しなくてはな らない。そのためには地籍明確化が個別地主の権利保護, 利益確保のためであってもさらに軍 用地の全体としてのまとまりに着眼したその活用に努力すべきであろら。

以上の諸点をふまえて，基地に関連して当面している開発の課題は次のように要約できるで 
あろら。

（1）成長動因として位置づけられない基地需要に代る新しい需要の創出を図ること。これ は基地需要中心に成立してきたサービス業その他の基地関連産業の構造を変えることである。

（2）基地からの所得を失う人々に対してその所得確保の手段を講ずること。これは換言す れば基地に利用されていた生産要素を産業として再編することである。単なる出稼ぎとか地主 とするのでなく産業の成立発展によって雇用機会をつくり, 所得確保, 增大を図らねばならな W。

（3）中南部における都市構造の 改善のために 軍用地転用を計画的に組み入れていくこと。 基地は市街地形成の無秩序を生み, 過密の原因ともなっているが，反面軍用地の位置，大きさ， まとまりに対しては今後都市構造の改善に際して充分な評価を与えるべきであろう。

（4）以上について, 国, 県および市町村の各レベルに扔ける政策主体が, 十分調整し, 計 画をたて実現に努力すること。

\title{
The U.S. Military Bases and Okinawan Economy
}

\author{
Isamu NAKASONE \\ (University of the Ryukyus)
}

It was the construction of military bases that had put the biggest impact on post-war Okinawan society. Construction and maintenance of bases for the U.S. Forces were to give signfiicant and overall changes in social, cultural, and economic conditions, as well as natural conditions, and resulted in the formation of present regional structures of population, land use, cities, and industries.

The purpose of this paper is to point out some problematic ecnomic aspects of military bases in Okinawa and give suggestion for regional economic development. 